\title{
Analisis Frekuensi Kompleks Gempa Tornillo Berdasarkan Data Seismogram Gunungapi Lokon Wilayah Sulawesi Utara Periode Mei 2017
}

\author{
Ida Pratiwi $^{*}$, Andi Suhandi ${ }^{1}$, Devy Kamil Syahbana ${ }^{1}$ \\ ${ }^{1}$ Departemen Pendidikan Fisika, Universitas Pendidikan Indonesia \\ Jl. Dr. Setiabudhi No. 299 Bandung 40154 \\ ${ }^{2}$ Pusat Vulkanologi dan Mitigasi Bencana Geologi, Jl. Diponegoro No. \\ 57,Cihaur Geulis, Cibeunying Kaler, Kota Bandung, Jawa Barat 40122 \\ *Penulis Penanggungjawab E-mail : : idapratiwi17@gmail.com
}

\begin{abstract}
ABSTRAK
Gunung api Lokon merupakan salah satu gunung api aktif di Indonesia. Gunung Lokon terletak di kota Tomohon, Sulawesi Utara. Salah satu jenis klasifikasi gempa bumi pada Gunung api yaitu gempa Tornillo. Gempa Tornillo terjadi pada gunung api yang berada pada wilayah sesar tepatnya zona rekahan dangkal dimana rekahan mengalami getaran karena terisi oleh fluida. Penelitian ini bertujuan untuk memahami kondisi dinamika fluida dalam tubuh Gunung api Lokon pada bulan Mei 2017 berdasarkan analisis frekuensi kompleks gempa Tornillo. Hasil penelitian ini dapat mengestimasi dinamika fluida Gunung api Lokon dan mengidentifikasi konten fluida maupun dinamika dimensi kerak. Penelitian ini menggunakan data seismik digital Gunung api Lokon yang terekam pada bulan Mei 2017. Metode yang digunakan dalam penelitian ini adalah metode SOMPI dengan parameter frekuensi kompleks yang terdiri dari frekuensi osilasi $(f)$ dan karakteristik peluruhan gelombang (Q-factor). Gempa Tornillo pada periode 13-22 Mei 2017, mempunyai distribusi nilai $Q$-factor berada pada rentang 50-500 dan frekuensi terdistribusi pada rentang 0,3-8 $\mathrm{Hz}$ dan nilai Q-factor dominan berada berada pada rentang 50-200 dengan frekuensi dominan terjadi pada rentang 2-3 Hz. Gempa Tornillo berada pada kedalaman dangkal yaitu kurang dari $1 \mathrm{~km}$. Hasil analisis frekuensi kompleks memperkirakan bahwa terjadi letusan pada Gunung api Lokon periode bulan Mei 2017, dengan estimasi tipe letusan adalah letusan freatik hingga freatomagmatik. komposisi fluida berupa misty gas, uap air dan partikel abu. Analisis frekuensi kompleks gempa Tornillo ini sangat bermanfaat dalam memperkirakan tipe letusan di masa yang akan datang.
\end{abstract}

Kata Kunci : Lokon; Frekuensi Kompleks; Tornillo; gunung api 


\begin{abstract}
Lokon volcano is one of the active volcanoes in Indonesia. Mount Lokon is located in Tomohon city, North Sulawesi. One type of earthquake classification on Volcano is Tornillo earthquake. Tornillo earthquake occurred at the volcano which is in the fault zone is precisely a shallow fracture zone where the fracture is vibration because filled by fluid. This study aims to understand the fluid dynamics conditions in the Lokon Volcano body in May 2017 based on the complex frequency analysis of Tornillo earthquake. The results of this study can estimate the dynamics of Lokon Volcano and identify the fluid content as well as the dimensional dynamics of the crust. This research uses Lokon volcano digital data recorded in May 2017. The method used in this research is SOMPI method with complex frequency parameters consisting of oscillation frequency (f) and waveform decay characteristic (Q-factor). Tornillo earthquake in the period May 13 to May 22, 2017, has a distribution of Q-factor values in the range 50-500 and distributed frequencies in the range 0.3-8 Hz and the value of the dominant Q-factor is in the range 50-200 with the dominant frequency occurs in the range 2-3 Hz. The Tornillo Earthquake is at a shallow depth of less than $1 \mathrm{~km}$. The result of complex frequency analysis is estimated that eruption at Lokon Volcano in period May 2017, with estimated eruption type is phreatic to freatomagmatic eruption. Estimation of fluid composition is misty gas, water vapor and ash particles. The complex frequency analysis of tornillo earthquake is very useful in estimation the type of eruption in the future.
\end{abstract}

Keywords : Lokon; Complex Frequency; Tornillo; volcano

\section{Pendahuluan}

Secara geografis Indonesia merupakan Negara Kepulauan yang terletak pada pertemuan tiga lempeng tektonik yaitu lempeng benua Eurasia, Lempeng Samudra Hindia dan Samudra Pasifik. Interaksi antar lempeng membentuk jalur pegunungan berapi yang membentang dari Sumatra ke Laut Banda, dilanjutkan sampai ke perairan Maluku dan Sulawesi Utara. Di sepanjang zona penujaman lempeng terdapat 129 gunung api yang masih aktif dari total keseluruhan sekitar 500 gunung api di Indonesia. Banyaknya gunung api aktif di Indonesia disebabkan karena Indonesia merupakan negara kepulauan yang berada pada daerah lingkaran gunung api (ring of fire) yaitu wilayah melingkar dimana batas-batas lempeng bertemu yang mengakibatkan munculnya banyak 
gunung api dan zona seismik aktif [1].

Salah satu gunung api aktif di Indonesia adalah gunung api Lokon yang terletak di Sulawesi Utara. Secara geografis gunung Lokon terletak pada $1^{\circ} 21^{\prime} 30^{\prime \prime}$ LU dan $124^{\circ} 47^{\prime} 33^{\prime \prime}$ BT dengan ketinggian 1579,5 meter diatas permukaan laut.

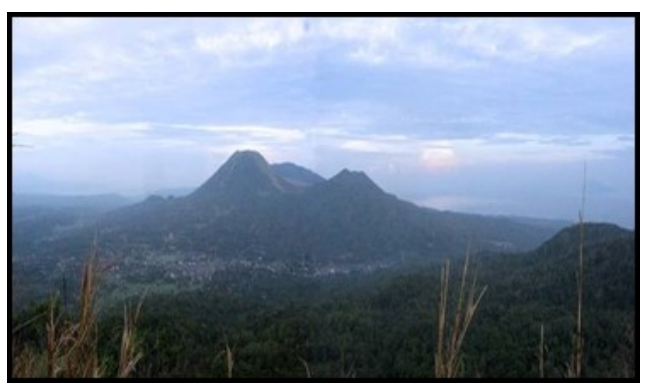

Gambar 1. Gunung Lokon Wilayah Sulawesi Utara [2]

Gunung api ini berdekatan dengan kota Tomohon dan merupakan salah satu gunung api yang sering mengalami erupsi. Dalam sejarahnya tercatat lebih dari 33 kejadian erupsi. Masa istirahat terpanjang gunung api ini adalah 64 tahun sedangkan masa istirahat terpendeknya 1 tahun. Berdasarkan bentuk morfologinya, puncak gunung Lokon berdampingan dengan puncak Empung dengan jarak antara keduanya 2,2 $\mathrm{km}$ sehingga merupakan gunung kembar yang sering disebut kompleks Lokon-Empung. Gunung Lokon termasuk gunung api dengan frekuensi kejadian erupsi tinggi [3].

Penelitian mengenai Gempa Tornillo pertama kali dikenalkan oleh Redoubt dan Necado del Ruiz serta erupsi yang terjadi di Galeras, Colombia pada tahun $1992-$ 1993. Gempa Tornillo dicirikan dengan bentuk gelombang yang menyerupai sekrup dan mempunyai peak frekuensi dominan yang tajam dan dalam range yang sempit. Gempa Long- period ditimbulkan oleh injeksi magma kedalam batuan disekitarnya, sehingga timbul tekanan terhadap batuan yang pada akhirnya timbul gempa [4] (Chouet, 1994). Gempa Tornillo juga terjadi pada zona rekahan dangkal (shallow fracture Zone) dimana rekahan mengalami getaran karena terisi oleh fluida.

Analisis frekuensi gunung api dilakukan untuk dapat mengetahui jenis fluida yang ada di dalam tubuh gunung Lokon sehingga dapat bermanfaat untuk memperkirakan tipe letusan di masa yang akan datang. Pada penelitian ini memfokuskan tentang aktivitas gunung Lokon dan analisis frekuensi gempa tornillo pada Gunung api Lokon yang terjadi pada bulan Mei 2017. Dengan parameter frekuensi kompleks terdiri dari frekuensi osilasi (f) dan faktor kualitas (Q-factor).

Analisis frekuensi ini menggunakan persamaan homogeneous auto regressive (AR) Kumazawa. Dengan frekuensi kompleks $f=i g$. Sedangkan untuk menentukan karakteristik peluruhan gelombang (Q-factor) sebagai berikut :

$$
Q=\frac{-f}{2 g}
$$


Dengan perhitungan $Q$ factor dari kejadian LP dapat dituliskan sebagai berikut:

$$
Q^{-1}=Q_{r}^{-1}+Q_{i}^{-1}
$$

dengan ,

$Q_{r}^{-1}:$ radiasi

$Q_{i}^{-1}:$ intrinsic losses

Dalam interprestasi variasi temporal frekuensi kompleks gempa Tornillo pada Gunung api Lokon, diasumsikan bahwa gempa Tornillo dihasilkan dari resonansi dari pengisian fluida (Fluid-filled) pada rekahan yang terdapat di gunung api dengan model rectangular. Karakteristik propertis dari pengisian fluida (sistem resonansi) pada sumber gempa Tornillo bisa langsung diindikasikan dari frekuensi kompleks berdasarkan peluruhan osilasi harmonik pada bagian ekor gelombang (coda) gelombang gempa Tornillo. Parameter fisik dari model rekahan Chouet rectangular fluid- filled berdasarkan rasio $\alpha / \mathrm{a}, \mathrm{b} / \mu, W / L$ dan

$$
C=\left(\frac{b}{\mu}\right)\left(\frac{L}{d}\right)
$$

dengan,
$\alpha$ : Kecepatan gelombang $\mathrm{P}$
a : Kecepatan fluida cair
$\mathrm{b}$ : Modulus Bulk fluida
$\mu$ : Rigiditas Solid
$\mathrm{W}$ : Lebar
L : Panjang
d : Celah

Konstanta Lame adalah modulus elastik batuan yang menggambarkan sifat inkompresi batuan. Konstanta Lame dapat ditentukan dari modulus elastik lainnya:

$$
K=\lambda+\frac{2}{3} \mu
$$

Rasio $\alpha / a$ dan $b / \mu$ berhubungan dengan densitas fluida ${ }^{(\rho f)}$ dan matriks batuan ( $\rho s)$. Hubungan dengan konstanta lame $\lambda=\mu$, bisa dituliskan sebagai berikut:

$$
\frac{\rho f}{\rho s}=\left(\frac{1}{3}\right)\left(\frac{a}{a}\right)\left(\frac{b}{\mu}\right)
$$

\section{Metode Penelitian}

Data yang didapatkan dari penelitian ini adalah data seismik Gunung Lokon periode Mei 2017. Dari data-data tersebut dilakukan analisis frekuensi kompleks dengan menggunakan metode SOMPI dan Metode GAD (Geiger's method with Adaptive Damping). Metode SOMPI berguna dalam menghitung spektral properties dari sinyal harmonik. Metode ini telah digunakan di beberapa gunung api seperti Kusatsu-Shirane, Japan, Tungurahua, Ecuador, Mount Spurr, Alaska US, Merapi, Taal, Philippines. Hasil frekuensi kompleks dapat berguna untuk estimasi dinamika fluida dalam tubuh gunung api. Software yang digunakan adalah Magma CAT 
1.0, langkah pertama yang dilakukan adalah mengconvert data SEISAN ke MSEED, kemudian memproses cut signal untuk dapat memplot sinyal gempa Tornillo pada periode Mei 2017. Maka akan dihasilkan grafik RSAM dan frekuensi dominan. Langkah berikutnya melalukan proses decay coda signal gempa Tornillo pada software Magma CAT 1.0.

Metode SOMPI yang dilakukan yaitu menstrukturisasi data gempa Tornillo gunung api Lokon kemudian melakukan proses sompi.tar. Selanjutnya data yang sudah di proses kemudian diolah dengan menggunakan MATLAB agar dihasilkan grafik frekuensi.

Untuk Penentuan hiposenter gempa Tornillo menggunakan Metode GAD (Geiger's method with Adaptive Damping), yaitu metode untuk mencari titik X, Y, Z, setiap gempa. Prosesnya adalah memasukan data hasil picking (arrival.dat), koordinat stasiun (station.dat) dan kecepatan (velocity.dat) yang disimpan dalam bentuk Notepad kemudian menjalankan dengan software GAD.

\section{Hasil Dan Pembahasan}

\section{Analisis Gempa Tornillo pada periode Mei 2017}

Gambar 2 merupakan hasil kejadian gempa Tornillo Gunung api Lokon yang terekam pada 3 stasiun yaitu stasiun Empung (EMP), stasiun Kinilau (KIN) dan stasiun Wailan (WLN) pada tanggal 14 Mei 2017 pukul 15:34:20 UTC. Empung (EMP), stasiun Kinilau (KIN) dan stasiun Wailan (WLN) pada tanggal 14 Mei 2017 pukul 15:34:20 UTC.

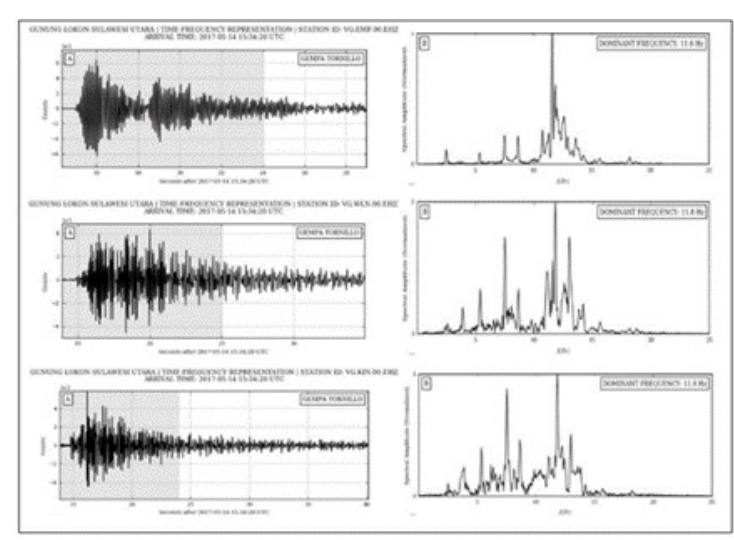

Gambar 2. Hasil kejadian gempa Tornillo dan grafik spektral amplitude yang terekam pada stasiun Empung (atas), stasiun Wailan (tengah) dan stasiun Kinilau (bawah) yang terjadi pada tanggal 14 Mei 2017.

Hasil grafik menunjukkan besarnya frekuensi yang didapat yaitu 11,8 Hz pada stasiun Wailan (WLN) dan stasiun Kinilau (KIN) yaitu $11.6 \mathrm{~Hz}$. Perbedaan antara ketiga stasiun tidak terlalu jauh, frekuensi dominan yang dihasilkan pada ketiga stasiun berkisar $11 \mathrm{~Hz}$. Hal ini disebabkan karena peak frekuensi gempa yang terekam pada ketiga stasiun tepat pada saat frekuensi nya $11 \mathrm{~Hz}$. Pada ketiga stasiun menunjukkan beberapa peak frekuensi dominan atau multichromatic.

Gempa Tornillo pada tanggal 13 Mei 2017 
Gambar 3 merupakan hasil grafik gempa Tornillo yang terjadi pada tanggal $13 \mathrm{Mei}$ 2017 pada pukul 20:22:20.026 Greenwich. Gambar a merupakan sinyal seismogram gempa Tornillo yang terjadi pada pukul 20:22:20.026 Greenwich dengan selisih waktu yang terjadi pada tanggal 13 Mei 2017 yaitu 18 detik.

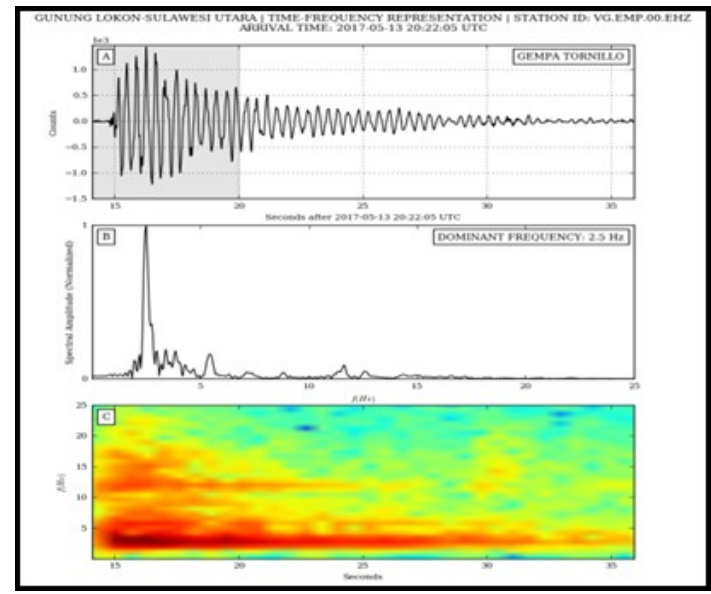

Gambar 3. Hasil Gempa Tornillo menggunakan software Magma CAT yang terjadi pada tanggal 13 Mei 2017.

Sedangkan durasi decay coda signal (Peluruhan sinyal) dimulai dari detik 22,0 sampai detik ke 34,4. Gambar b merupakan Frekuensi dominan yang diperoleh pada kejadian gempa Tornillo dengan rentang frekuensi yang terjadi yaitu 0-20 Hz. Gempa Tornillo dicirikan dengan bentuk gelombang yang menyerupai sekrup yang mempunyai satu peak spektrum dominan (monochromatic) dengan frekuensi dominan yaitu $2,5 \mathrm{~Hz}$. Sedangkan gambar c merupakan grafik real-time frekuensi terhadap waktu yang dihasilkan dari hasil seimogram gempa Tornillo dengan lamanya gempa yaitu 18 detik.
Gambar 4 merupakan grafik gempa Tornillo yang terjadi pada tanggal $14 \mathrm{Mei}$ 2017 pukul 01:28:17.676 Greenwich.

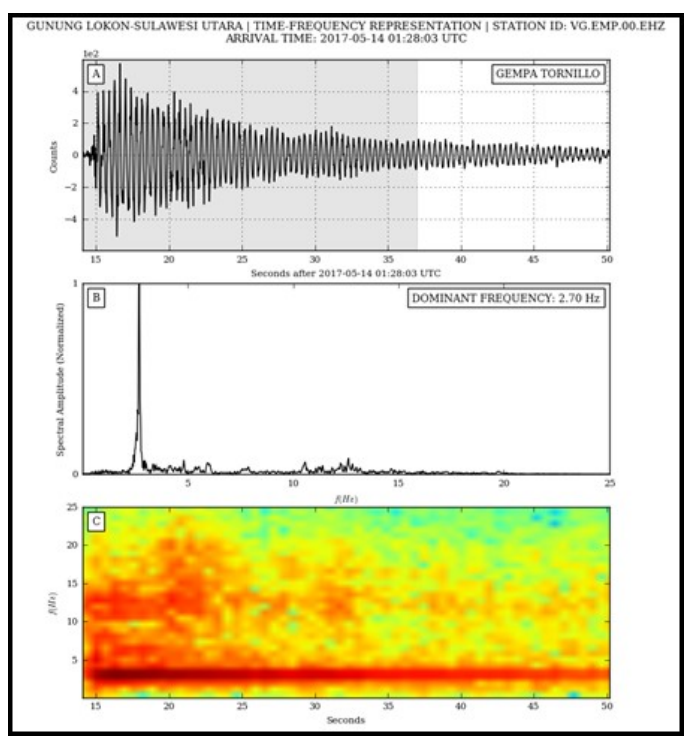

Gambar 4. Hasil gempa Tornillo yang terjadi pada tanggal 14 Mei 2017.

Gambar a merupakan grafik sinyal seismogram gempa Tornillo dengan lamanya gempa yang terjadi sekitar 37 detik dengan durasi decay coda signal (peluruhan sinyal) dimulai dari detik 20,5 sampai detik 42,7. Gambar b merupakan grafik spektral amplitude dengan frekuensi dominan sebesar $2,7 \mathrm{~Hz}$ dan rentang frekuensi sebesar $0-20 \mathrm{~Hz}$ dan terdiri dari satu peak frekuensi dominan (monochromatic). Gambar c merupakan hasil grafik real-time frekuensi yang dihasilkan dari sinyal seismogram dengan menggunakan magma CAT 1.0.

\section{RSAM Gunung Lokon Mei 2017}

Berdasarkan gambar 5 merupakan hasil RSAM gunung api Lokon bulan Mei 
2017. Stasiun yang diamati adalah stasiun empung (EMP) dengan grafik yang dihasilkan yaitu grafik mengalami kenaikan amplitude yang konstan pada tanggal 1 Mei -5 Mei 2017 sebesar 0-25 A.U dan mengalami penurunan pada tanggal 7 Mei 2017 dengan amplitude nya 3 A.U dan mengalami kenaikan amplitude yang sama pada tanggal 8 Mei 2017 yaitu 0-25 A.U, jika diamati berdasarkan grafik RSAM pada bulan Mei 2017 banyak terjadi gempa hembusan dan aktivitas vulkanik.

\section{Frekuensi Dominan Gunung Lokon} Periode Mei 2017

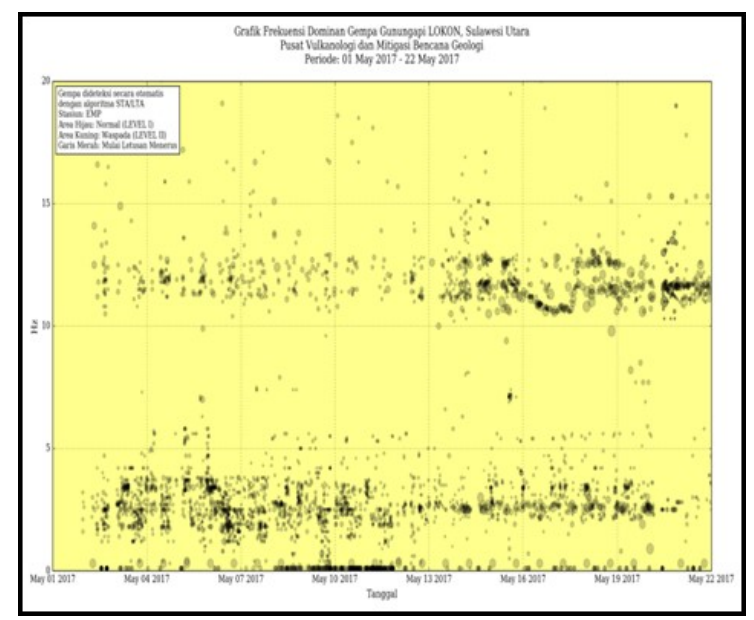

Gambar 6. Frekuensi Dominan Gunung Lokon Mei 2017.

Berdasarkan grafik 4.14 menunjukkan bintik hitam banyak menumpuk pada tanggal 14 Mei-22 Mei 2017. Jika dilihat pada gambar 4.13. Grafik harian gunung api Lokon pada tanggal 14-22 Mei 2017 banyak terjadi gempa hembusan dan adanya aktivitas vulkanik dengan frekuensi dominan yang terdeteksi yaitu $10-12 \mathrm{~Hz}$ (frekuensi tinggi). Rentang frekuensi tinggi yang terjadi pada tanggal 14-22 Mei 2017 disebakan karena adanya aktivitas vulkanik yang terjadi akibat kegiatan magma atau gas, pembentukan rekahan atau retakan, atau kegiatan hidrotermal yang terjadi di dalam gunung api Lokon.

\section{Hiposenter Gunung Lokon}

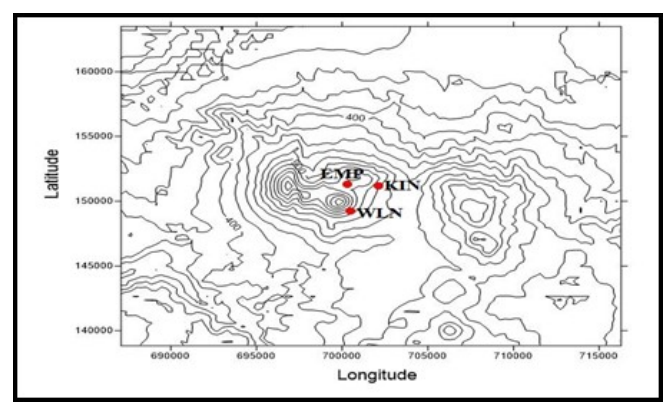

Gambar 7. Sebaran Kontur Gunung Lokon.

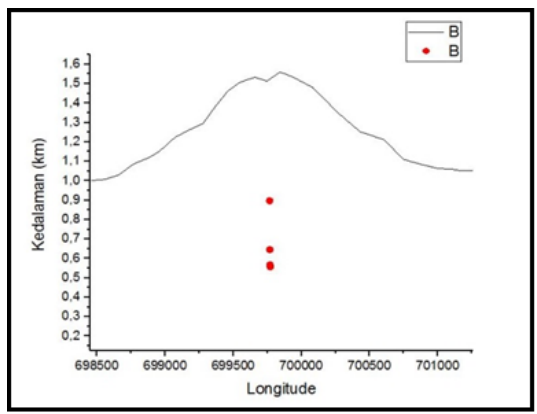

(a)

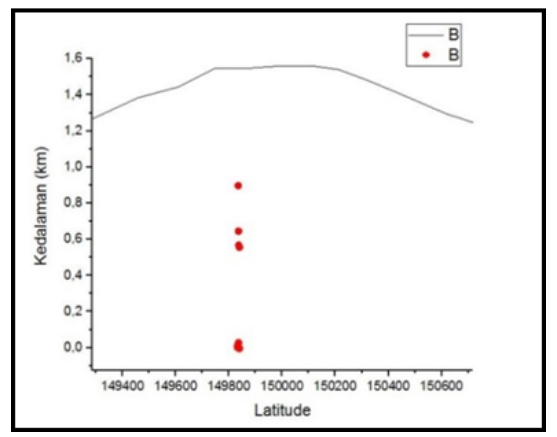

(b)

Gambar 8. Hasil hiposenter (a) Penampang Barat-Timur dan (b) Lintang Utara-Selatan 
Gambar 7 dan gambar 8 diatas memperlihatkan bahwa gempa Tornillo terjadi pada kedalaman kurang dari $1 \mathrm{~km}$. Gempa Tornillo paling dangkal terjadi pada $0,57 \mathrm{~km}$ dan paling dalam terjadi pada $0,87 \mathrm{~km}$ dibawah permukaan laut. Hiposenter gempa Tornillo pada Gunung Api Lokon berada di sekitar kawah Tompulan dengan kedalaman gempa Tornillo lebih dangkal dari $1 \mathrm{~km}$, hal ini merupakan hal yang umum teramati untuk lokasi gempa Tornillo karena posisinya bersumber pada kerak-kerak atau rekahan di dekat permukaan akibat dari pergerakan fluida hidrotermal atau magmatik.

\section{Analisis Frekuensi Kompleks}

\section{Growth Rate}

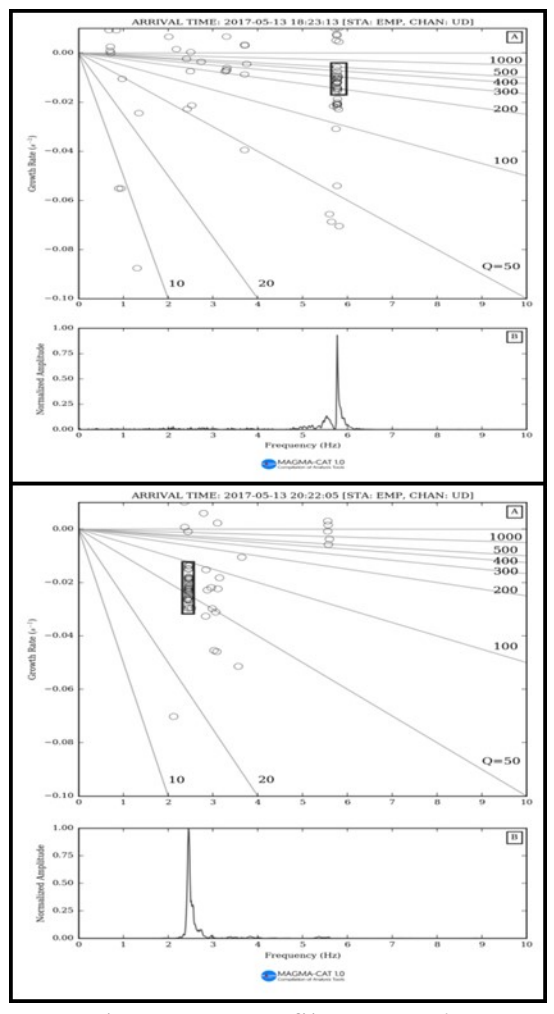

Gambar 9. Grafik growth rate terhadap frekuensi $(f-g)$.
Gambar 9 merupakan grafik growth rate (tingkat pertumbuhan) gelombang harmonik pada kejadian Tornillo. Hal ini sesuai dengan grafik frekuensi karakteristik gempa Tornillo yang hanya mempunya puncak peluruhan pertama monokromatik dan sesuai dengan grafik frekuensi gempa Tornillo yang pernah diamati pada gunung Papandayan (Syahbana, 2014) yang terjadi pada tanggal 13 Mei 2017 dengan frekuensi dominan $6 \mathrm{~Hz}$ pada pukul 18:23:13 UTC dan frekuensi dominan $2,5 \mathrm{~Hz}$ pada pukul 20:22:05 UTC. Grafik growth rate menunjukkan frekuensi osilasi yang dominan. Lingkaran yang terkumpul pada grafik growth rate mengindikasikan hasil dominan yang akan digunakan dalam analisis variasi temporal pada kompleks frekuensi.

\section{Q-factor dan frekuensi Osilasi}

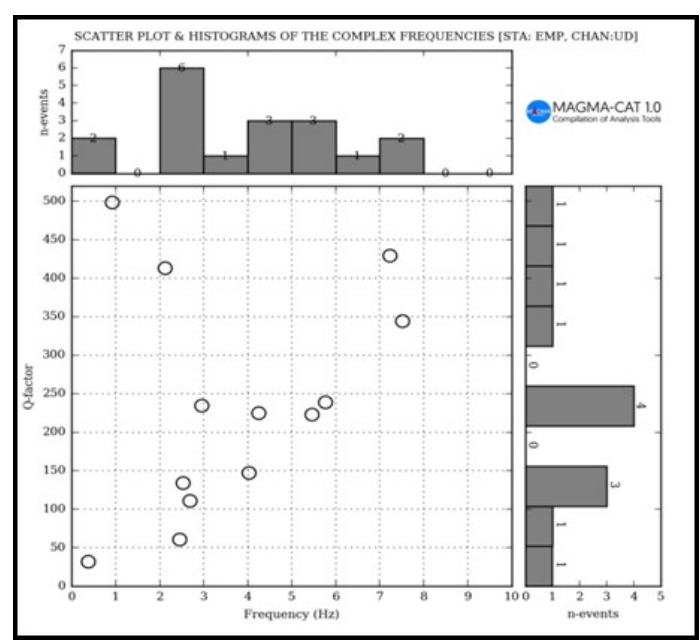

Gambar 10. Scatter Plot dan Histogram 
Gambar 10 merupakan scatter plot dan histogram frekuensi kompleks gunung Lokon pada periode Mei 2017 yang menunjukkan bahwa frekuensi dominan dari gempa-gempa Tornillo tidak hanya berada pada frekuensi tertentu, setiap gempa Tornillo memiliki frekuensi yang berbeda-beda. Namun demikian gempa Tornillo yang paling banyak terekam memiliki frekuensi dominan sekitar 2-3 $\mathrm{Hz}$ dan juga ada beberapa gempa Tornillo yang banyak terekam pada frekuensi 4-6 $\mathrm{Hz}$.

Parameter yang dipakai untuk mengukur secara kuantitatif atenuasi gelombang (peluruhan gelombang) yaitu menggunakan faktor kualitas Q. Dalam seismologi, parameter Q disebut dengan seismic quality factor ( $\mathrm{Q}$ factor), dimana nilai Q tinggi umumnya memiliki frekuensi yang rendah. Dari hasil analisis kompleks frekuensi, Q-factor yang diperoleh terdistribusi antara 50 sampai 500. Q-factor (fungsi atenuasi) dominan berkisar antara 50 sampai 200. Berdasarkan nilai Q-factor tersebut maka kemungkinan bahwa fluida yang ada di dalam kerak di bawah gunung Lokon pada saat ini dapat berupa uap air dan terdapat kemungkinan beberapa partikel abu. Untuk gempa-gempa Tornillo yang berkisar 50-200 dapat diperkirakan bahwa fluida yang mengeksitasi resonansi di dalam kerak utamanya berupa uap air (misty gas).

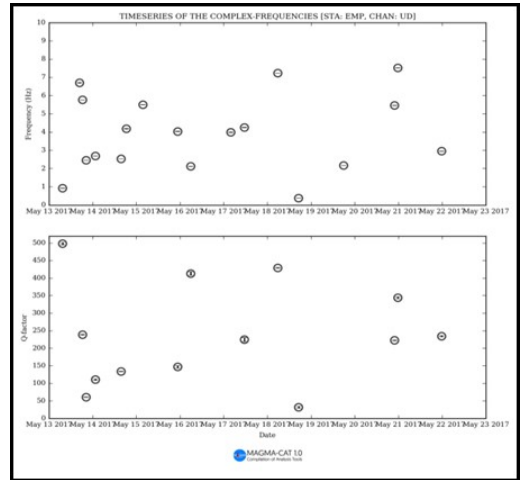

Gambar 11. Timeseries dari Frekuensi Kompleks Gunung api Lokon (a) Frekuensi Osilasi, (b) Q-factor.

Gambar 11 merupakan hasil plotting frekuensi osilasi dan $Q$ factor terhadap waktu. Berdasarkan gambar 11 (a), untuk kisaran frekuensi rendah ditemukan adanya pola yang mengidentifikasi perubahan dimensi kerak, yaitu pola penurunan dan peningkatan dari frekuensi osilasi. Gempa Tornillo yang terjadi pada perode 13 Mei-22 Mei 2017 merupakan proses dinamika fluida yang non-destruktif (belum teramati indikasi penumpukan stress/tekanan yang signifikan karena tidak diikuti oleh letusan).

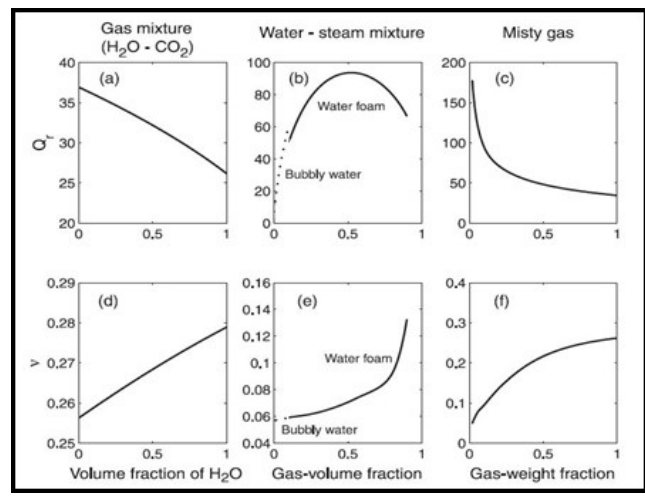

Gambar 12 Qr dan v untuk konten fluida hidrotermal yang berbeda jenis; (a,d) Gas mixture $\left(\mathrm{H}_{2} \mathrm{O}-\mathrm{CO}_{2}\right) ; \quad(\mathrm{b}, \mathrm{e})$ Water-steam mixture; (c,d) Misty gas [5] 
Hasil analisis karakteristik peluruhan gelombang ( $\mathrm{Q}$ factor), menunjukkan bahwa nilai Q lebih cenderung terdistribusi pada nilai dibawah 200 dan nilai Q- factor yang paling tertinggi adalah 500 (Gambar 12 b) Dalam kisaran nilai Q tersebut, fluida yang mungkin mendominasi aktivitas gunung api Lokon pada tanggal 13 Mei 2017 hingga 22 Mei 2017 adalah Misty gas (uap air) untuk kisaran nilai Q-factor dibawah 200 (Gambar 12). Fluida lain yang mungkin terdapat di dalam tubuh gunung api Lokon adalah partikel abu untuk nilai $Q$ factor diatas 200 .

\section{Kesimpulan}

1. Keadaan dinamika fluida pada gunung api Lokon periode Mei 2017 berdasarkan analisis frekuensi yang dilihat dari nilai $\mathrm{Q}$ (peluruhan gelombang) yaitu berada pada rentang 50-500 dengan rentang frekuensi yang terjadi yaitu 0,3-8 $\mathrm{Hz}$ memiliki kandungan komposisi fluida berupa partikel abu dan frekuensi dominan yang terjadi pada gunung api Lokon yaitu berada pada rentang 50-200 dengan rentang frekuensi yang terjadi yaitu $2-3 \mathrm{~Hz}$ memiliki kandungan komposisi fluida misty gas, uap air. Dengan tipe letusannya diperkirakan adalah freatik hingga freatomagmatik dengan demikian jumlah maupun energi gempa Tornillo yang terekam belum terlalu signifikan.

2. Berdasarkan sebaran hiposenter gempa Tornillo pada periode Mei 2017 maka diperoleh informasi bahwa kedalaman gempa yang terjadi pada gunung Lokon yaitu gempa berada pada kedalaman dangkal dan berada dibawah permukaan kawah Tompulan dengan energinya relatif rendah daripada gempa vulkanik sehingga tidak terjadi erupsi pada periode Mei 2017.

3. Berdasarkan karakteristik frekuensi kompleks gunung api Lokon maka frekuensi dominan yang terjadi pada gunung Lokon tanggal 1-22 Mei 2017 menunjukkan rentang frekuensi rendah yang dihasilkan sebesar $0-2 \mathrm{~Hz}$ pada tanggal 8-12 Mei 2017. Sedangkan rentang frekuensi tertinggi terjadi pada tanggal 14-22 Mei 2017 hal ini berkaitan dengan aktivitas vulkanik dan adanya gempa hembusan.

\section{Referensi}

1. Welayaturromadhona, W., Susilo, A., \& Triastuty, H. Physical Analysis of Mount Talang-West Sumatera Activity Based on the 
Spectral Characteristics and

Hypocenter Estimation of Volcanic

Earthquakes. Brawijaya Physics

Student Journal, 1(1).

2. PVMBG. Data Dasar Gunung Lokon.

Pusat Vulkanologi dan Mitigasi

Bencana Geologi: Bandung.

3. Kristianto dan Hendra Gunawan, 2012. Gejala awal letusan Gunung Lokon Februari 2012-Maret 2012. Jurnal Lingkungan dan Bencana Geologi, Vol. 3 No.3. Bandung

4. Choute, B.A., Page., R.A., Stephens, C.D., Lahr, J.C., Power, J.A., 1994. Precursory Swarms of Long-Period Kejadians at Redoubt Volcano (19891990), Alaska: Their Origin and Use as a Forecasting Tool. J. Volcano. Geotherm Res.62,95-135.

5. Kumagai, H., Choute, B.A., 2000. Acoustic Properties of a Crack Containing Magmatic or Hydrothermal Fluid. J. Geophysics Res. Solid Earth 105,25493-25512.

6. Syahbana, D.K., 2014. Fluid Dynamics Inside a "Wet" Volcano Inferred from Complex Frequencies of Long-Period (LP) Kejadian. J. Volcano. Geotherm. Res. 280, 76-89. 